\title{
THE EFFECTIVENESS OF WHISPERING GAME TO STUDENTS' LISTENING SKILL
}

\author{
Juwita Boneka Sinaga \\ English Dept, Unrika, Batam \\ Email: juwitaboneka@gmail.com
}

\begin{abstract}
In this research We will find the problem in learning process in the class especially in listening laboratory. The problems are the students do not know what is the meaning of what are they listening from the conversation or the teachers explanation. This research has purpose to students' listening skill by using whispering game at second semester English Department UNRIKA academic Year 2016/2017. This research is quantitative research. The researcher used total sampling. The experimental class was taught byusing whispering game, whereas the control class was taught using lecturing method. In this research, the researcher gave 20 of questions in multiple choices form. The result of analysis can be concluded that there was significant effect. It was showed $t_{\text {count }}>t_{\text {table }}(3,01>2,01)$ so $H_{0}$ was rejected and $H_{a}$ was accepted. The result of analysis can be concluded that the use of whispering game at Second semester UNRIKA in academic Year 2016/2017 gave significant effect in the students' activity in learning process than the use of close procedure.
\end{abstract}

Keywords : Whispering Game, Listening skill

\section{INTRODUCTION}

In this research we know that language has important rule for human life especially for communication. English is one of International language. We use English, especially for communication to other people who comes from different countries in the world. English is used many aspects such as business, technology, science, and education. In Indonesia the government inserted English in the school curriculum component from elementary school until university level. Teaching English as foreign language is not easy because English is a foreign language. Therefore the teachers have responsibility to teach student to understand the lesson.

In learning process, students often got the difficulties in understanding the lesson because the students do not listen carefully and lack of motivation in learning English. Therefore 
teacher should use an appropriate method and technique in teaching process. So the student can understand and enjoy in learning process. According to Hornby (1995) in Azar (2012:252) defines English is the total number of words in a language. In order to master English, student need to know and on the statement, it understand vocabularies in different context. cannot understand the listening material is one of the students' difficulty. There are some ways to understand the students' difficulties in listening, one of it is we must indicate the some factors that become problem in listening. In a study that conduct by Bennui (2007:5) at Thaksin University showed factors that influencing English as a Second Language (ESL)/ English as a Foreign Language (EFL) students' listening performance are students factors, speaker factors, characteristics of the spoken language, classroom facilities and teaching method factors. According to Arief and Adnan (2013:50), listening is considered as the language acquisition form. It means a new baby starts acquire a language by listen the voice in around of environment before starts to speak and learn the other skill, like read and write. Based on explanation above, the writer concluded that listening is paying attention activity to receive and understand what the speaker said before produce the other skills. In the other hand, listening becomes important in human language development.

The next problem is concerned with the technique of teaching English and media used. The teaching of English needs more attention because Listening skill is important in language proficiency. Teacher should prepare all the component in teaching learning process well. The component are the media, the material, and teaching method. Games are usually used for teaching language for young learners, because it is fun and motivating. Learning by games is suitable for young learner, give the student opportunity to learn her language experience through fun and play. According to Ngunyen and Khuat (2003:14) game brings relaxation and fun for student, to help them learn and retain words more easily. Whispering game is one method that can be applied in teaching English to improve vocabulary.

The researcher focused on the whispering game. The researcher limits the problem of the study about the effectiveness of whispering game to students' Listening skill at the Second semester UNRIKA. Based on the limitation above, the problem of the research can be formulated as follows; Is there any significant effect of whispering game to students' Listening skill at Second semester UNRIKA in the academic year of 2016/2017 . Based on the formulation above, 
the research had the objective of the study is to identify whether whispering game is effective to students' Listening skill or not at of Second semester UNRIKA in academic year 2016/2017.

Blachowicz \& Watts-Taffe in Ebrahimi (2005:6) state Englishis an essential means of interchanging ideas and of acquiring new experiences. In brief, Englishcan be defined as a number of English(words) in a language which contains information about its meaning, form, and usage in context of communication. It is the basic knowledge that students should master first before mastering English. From the definitions above, it can be concluded that Englishis the knowledge of words and word meanings.

\section{METHODOLOGY}

The kind of this research was an experimental research It was the type of research which focused on establish the cause-effect relationships. According to Sugiyono (2013:72), experimental research is a research method that used to find influencing a treatment to the other in controlled condition. In this research, the researcher analyzed the effectiveness of whispering game to students' Listening skill.

The experimental design must have two groups: an experimental group and control group.

\section{Hypothesis Testing}

According to Arikunto (2006:311), t-test of two independent variables are done to compare both variables whether they are similar or different. The T-test formula was taken from Arikunto(2006:311). The formula can be seen as below :

$$
\mathrm{t}_{\mathrm{test}}=\frac{M_{\chi}-M_{y}}{\sqrt{\left\{\frac{\sum x^{2}+\sum y^{2}}{N_{x+N_{Y}}-2}\right\}\left\{\frac{1}{N_{X}}+\frac{1}{N_{Y}}\right\}}}
$$

Where:

$M=$ The mean of each group 
$\mathrm{N}=$ Total of sample

$\mathrm{x}=$ Deviation for each value $\mathrm{X}_{2}$ and $\mathrm{X}_{1}$

$\mathrm{Y}=$ Deviation of each value $\mathrm{Y}_{2}$ and $\mathrm{Y}_{1}$

\section{Statistical Hypothesis}

The writer formulated the statistical hypothesis as follow :

Ho : Is accepted if $t_{\text {test }}<t$ table. It means that Whispering Game does not give significant effect to students' Listening skill at of Second semester UNRIKA in academic year 2016/2017.

Ha : Is accepted if $t_{\text {test }}>t_{\text {table. }}$ It means that Whispering Game gives significant effect to students' Listening skill at of Second semester UNRIKA in academic year 2016/2017.

\section{RESULT}

\section{Testing Instrument}

\section{Normality Test}

The statistic formula of Normality test used chi square's formula.

The summary of Normality test could be seen at table below:

Table. 1. Summary of Normality Testing

\begin{tabular}{|c|c|c|c|c|c|}
\hline No. & Variable & $\mathbf{X}^{2}$ count & $\mathbf{X}^{2}$ table & Note & \\
\hline 1 & $\begin{array}{l}\text { Listening skill of } \\
\text { Experimental Class in } \\
\text { Pre Test }\end{array}$ & 8.29 & 11.070 & $\begin{array}{c}\mathbf{X}^{2} \text { count }<\mathbf{X}_{\text {table }}^{2} \\
\text { Normal Distributed }\end{array}$ & \\
\hline 2 & $\begin{array}{l}\text { Listening skill of } \\
\text { Experimental Class in } \\
\text { Post Test }\end{array}$ & 9.96 & 11.070 & $\begin{array}{c}\mathbf{X}^{2} \text { count }<\mathbf{X}_{\text {table }}^{2} \\
\text { Normal Distributed }\end{array}$ & \\
\hline 3 & $\begin{array}{l}\text { Listening skill of } \\
\text { Control Class in Pre } \\
\text { Test }\end{array}$ & 4.92 & 11.070 & $\begin{array}{c}\mathbf{X}^{2} \text { count }<\mathbf{X}_{\text {table }}^{2} \\
\text { Normal Distributed }\end{array}$ & \\
\hline 4 & $\begin{array}{l}\text { Listening skill of } \\
\text { Control Class in Post } \\
\text { Test }\end{array}$ & 4.92 & 11.070 & $\begin{array}{c}\mathbf{X}^{2} \text { count }<\mathbf{X}_{\text {table }} \\
\text { Normal Distributed }\end{array}$ & $\begin{array}{r}\text { It could be } \\
\text { drawn as a }\end{array}$ \\
\hline
\end{tabular}


conclusion that the data were normally distributed. Because all of the results of $\mathrm{X}^{2}$ count was lower than $\mathrm{X}^{2}$ table.

\section{Homogeneity Test}

The formula of homogeneity test used formula by Riduwan (2011:186) as follow:

$$
\mathrm{F}=\frac{\text { The biggest variance }}{\text { The lower variance }}
$$

The summary of Homogeneity test could be seen at table below:

Table. 2. Summary of Homogeneity Testing

\begin{tabular}{|c|l|c|c|c|}
\hline No & \multicolumn{1}{|c|}{ Variable } & F count & F $_{\text {table }}$ & Conclusion \\
\hline 1 & $\begin{array}{l}\text { Listening skill in Pre } \\
\text { Test }\end{array}$ & 1.080 & 1.984 & Homogeneous \\
\hline 2 & $\begin{array}{l}\text { Listening skill in Post } \\
\text { Test }\end{array}$ & 1.392 & 1.984 & Homogeneous \\
\hline
\end{tabular}

The table above showed that the values of $f_{\text {countwas }}$ lower than the value of $\mathrm{f}_{\text {table }},\left(\mathrm{f}_{\text {count }}<\mathrm{f}_{\text {table }}\right)$. It indicated that the datas from pre test and post test were homogeneous.

Based on the statistical analysis of hypothesis testing above, the writer discussed the treatment of Whispering Game in students' Listening skill. It was found that the students who were taught by whispering game have been improved in parts students' Listening skill than the students who were taught by using lecturing method because the students who were taught by whispering game can easily increase new vocabulary. Students could be easier and enjoy to understand in learning process. Based on the data analysis about students' Listening skill, the writer found out that the mean of students in experimental class was higher than the mean of students in control class, then the tcount was higher than table (3.01> 2.01), which means the Null Hypothesis is accepted, so that whispering game was give significant effect to students' Listening skill at of Second semester UNRIKA.

\section{DISCUSSION}


Juwita: The Effective of Whispering.....................

Based on the research conducted for Second semester UNRIKA. The sum score of experimental group for pre-test was 1.290 , while the score post-test was 1.740 . It showed that in experimental group there was significant different between pre-test and post-test score ( 1.740 1.290 ) was 450 . Which the post-test was higher than pre-test score. The sum score of control group for pre-test was 1.320 , while the score post-test was 1.565 . In the control group that showed there was significant different between pre-test and post-test score (1.565-1.320) was 245 which the post-test was higher than pre-test score. Based on the explanation, it was shown the students that who got treatment by using whispering game obtained more significant improvement than the students who got treatment with close procedure.

The result of the research of test also proved that whispering game gave significant effect to students Listening skill. It was shown from the calculation between pre-test and post-test score. In the pre-test, calculation both of group experimental and control group the value $\mathrm{t}$ obtained was 3.01 while the value of $t$ table was 2.01 with the level of significant 0.05 . It showed that the value of t table (2.01), was smaller than the value of t obtained was (3.01). it means that the alternative hypothesis was accepted.

The implication for student and teacher are:

\section{Students}

Students can increase Listening skill so they will master in four English language skills that are speaking, reading, writing, and listening. Students will be easier and enjoy to understand in learning process

\section{Teacher}

Whispering game is easy to use in teaching Listening skill. This method can help the teacher in learning English teacher so that students will be easier to know and understand the lesson and student interesting in learning english..

There are suggestions proposed for the next studies in the similar field as the present field as the present research. The suggestion are in regard with practical development and professional development. Dealing with the practical development, the use of Whispering Game can be applied in teaching English in Listening skill.

To have a certain competences the teacher should be able to select the right and appropriate topic for students in term of learning objectives and students needs and interest. Moreover, the teacher also should have capability in designing and presenting the material for 
the students. As a result, the students will be more interest and easier in comprehending the material.

Dealing with the research finding, the following suggestion as the outcomes of the study is put forward. Those are expected to be useful for come writer, the teacher English, and for whom that may be concerned with English education and particularly teaching vocabulary.

\section{REFERENCES}

Arikunto. (2012). Dasar-Dasar Evaluasi Pendidikan. Jakarta: Bumi Aksara.

Azar A.(2012). The Effect of Games on EFL Learners' EnglishLearning Strategies: Maragheh Branch-Islamic Azad University. Iran.

Ebrahimi \& Zamanian. (2014). Implementing Practical Game on Iranian Early EFL Learners. Iran.

Ngunyen \& Khuat. Learning EnglishThrough Games. Vietnam.

Sugiyono. (2013). Metode Penelitian Kuantitatif,Kualitatif, dan R\&D. Jakarta: Alfabeta.

Sunarto \& Riduwan. (2012). Pengantar Statistika. Bandung: Alfabeta Bandung.

Arief, Eka J and Adnan, A. (2013).The Use of Dictogloss Method in Teaching Listening A Hortatory Exposition Text at Senior High School. Journal of English Language Teaching, Vol. 2 No. 1, September 2013, Serie A.Publish byFBSState University of Padang.

Bennui, P. (2007). A Survey on First Year Students' Opinions Concerning Courses of Their Low Performance in Listening in the English II Course at Thaksin University Phattalung. Thailand.Journal of Western Language, Humanities and Social Science. Publish by Thaksin University Songkhla, Thailand. 